Although Canada aspired to lead the field of aircraft technology, the willingness of these leaders, along with the voters, to make the continued investment required for the development of cutting edge fighters was constantly challenged by Canada's industrial inexperience and economy of scale relative to its southern neighbour. The final CF-100 was not ready, or built in sufficient quantity, to meet the increasing requirements for home defence and Canada's international commitments during the Korean War. As a result, it was determined that the needs of the Air Force could be solved by a reliance on the American designed F-86. The Air Force officers could no longer convince the political leadership that Canada could rely solely on a domestic capability to design and build combat aircraft. After the war was over, threat assessments were reduced considerably and, with them, the defence budget.

The ability to meet both budget and schedule on the most complex military capabilities ever designed has been, and always will be, an elusive goal for most national procurement programs. There are a multitude of variables involved in a platform's production and it is not simply the case of A.V. Roe performing poorly. Wakelam correctly argues that in the face of competing priorities, the CF-100 was a valiant effort and Canadian engineers did demonstrate exceptional skill and independence in creating an indigenous fighter capability. Although the Air Force was never able to field a fully domestic solution for its fighter needs, and Belgium turned out to be the only international customer, for a time it did provide the best jet - and engine - in the NATO arsenal. The historical analysis of case studies in Canadian equipment procurement is extremely limited and the historiography has certainly profited from Wakelam's exploration of the interplay between government, industry, and the military during the procurement process.

Aaron Plamondon

Mount Royal University

\title{
Carol Silverman, Romani Routes: Cultural Politics and Balkan Music in Diaspora (New York: Oxford University Press, 2012).
}

Carol Silverman has spent many years working with Roma communities in Macedonia and New York, researching them and performing with them. We have read her on the subject many times in the past, but her experience, knowledge, and insight are now gathered together in this landmark volume. Given the title, it is worth pointing out that the focus is clearly on Macedonian Roma. There are sideways glances to neighbouring Bulgaria and Kosova (cue research by Donna Buchanan and Svanibor Pettan), but not to Greece, Romania, or other parts of Former Yugoslavia. This is reflected in the bibliography, which makes 
little reference to texts on Roma from these regions, nor (and this is more surprising) to major literature in languages other than English and Macedonian/Bulgarian.

It is in the nature of this topic that several of Silverman's stories have been told in detail elsewhere. Roma have their own narratives for sure, but they also participate in the narratives of others, and some of the unfolding sociopolitical history of the eastern Balkans (pre- and post-1989), together with generic histories of Bulgarian 'wedding music' and chalga, not to mention Yugoslav neo-folk, is well-rehearsed. You can't really blame Silverman for these overlaps with existing scholarship - she has to provide a backcloth for her ethnography - but I for one found myself skimming certain sections of the book, and then slowing down when I reached the detailed case studies. For by far the best parts of this book are those in which we hear the voices of Silverman's informants and friends speaking directly. In particular, the chapter on Yuri Yunakov should be singled out, not just for the intrinsic interest of Yunakov's story, but because of the skill with which Silverman allows that story to light up so many issues germane to Roma experience. At times in this chapter, and elsewhere too, I felt that music was almost incidental to the larger message.

We are privileged to have access to Silverman's unique insights into Rom communities both in the Balkans and the US, and I really do applaud her achievement. There is nothing else so detailed, and we will all be dipping into Romani Routes for years to come, to say nothing of exploring the accompanying website. Yet in some ways it is a frustrating book. Partly it is the overlaps with other studies and the internal, cross-chapter, repetition. But mainly it is the abrupt changes in discursive tone, together with Silverman's failure to make the most of her extraordinary breadth and depth of knowledge of the music and musical life of the Roma. Let's take the matter of tone. When she is not telling colourful, up-close stories about individuals, Silverman appropriates a discourse typical of the North American college circle, including the usual self-positioning, and the familiar stiff, over-conscientious theorising about things that often boil down to common sense (we seldom get her view of anything until everyone else's view has been duly recited and referenced). This doesn't always make for a great read, and it certainly results in clunky gear changes when we get to the case studies, where the language relaxes and we are genuinely engaged.

As to not making the most of her knowledge, this is more difficult. It may even be unfair, and more a reflection of my own very different approach to scholarship than a comment on Silverman. It is certainly to her credit that she avoids binaries and stereotypes, and that her detailed ethnographies enable a nuanced view of the experience of Roma as they negotiate with ever-changing 
political realities. All this is well done. But I search in vain for useful generalisations about their music and music-making, for all the abundance of generic and stylistic descriptions. The subject-matter of Silverman's book could have afforded an ideal opportunity for scrutiny of, and reflection upon, music as a cultural practice, to take one example. I can imagine employing theory in potentially revelatory ways here: looking at Rom praxes from the contrasted perspectives of Pierre Bourdieu and Alasdair McIntyre, for instance, so that the spotlight swings from politics to ethics and back again; or allowing Rom music-making to raise broader questions about the relationship between determinate texts (notation is irrelevant here) and improvisation, or about the status of performance (and performers) as components of history. The singularity of this whole topic, positioned at an angle to both traditional music and popular music, positively begs for some such treatment, in my view. But I may be guilty here of the cardinal sin of functional judgments: criticising a book for failing to achieve what was never in its sights. In the end, Silverman's book is what it is; and it is immensely useful.

Jim Samson

Royal Holloway, University of London

\author{
Victoria W. Wolcott, Race, Riots, and Roller Coasters: The Struggle Over \\ Segregated Recreation in America (Philadelphia: University of \\ Pennsylvania Press, 2012).
}

Race, Riots and Roller Coasters explores the efforts to desegregate American public recreation sites from the 1920s to the 1970s. Wolcott demonstrates how recreational sites in both the North and the South were important battlegrounds in the $20^{\text {th }}$ century African American freedom struggle. She highlights how the desegregation of recreational sites fits into the more explored stories of housing, transportation, school, and service desegregation, as well as the histories of key civil rights organizations, but she also demonstrates why it is important to understand how a study of recreational desegregation subverts our traditional understanding of amusement in the United States and the civil rights movements. She states that "popular memories of mid-twentieth century urban amusements are replete with nostalgia and rarely contain references to segregation" and that full access to public and recreational sites was "central to the freedom struggle because it is itself a central freedom" $(4,232)$.

Beyond adeptly demonstrating the importance of recreational desegregation in the United States, Wolcott makes several other significant interventions in our understanding of the African American freedom struggle. Her study con- 